\title{
ECONOMIC SECURITY MANAGEMENT OF FINANCIAL INSTITUTIONS AS OBJECTS OF THE STATE CRITICAL INFRASTRUCTURE
}

\section{Nataliia Zachosova}

Bohdan Khmelnytsky National University of Cherkasy, Cherkasy, Ukraine

\section{Zinaida Zyvko}

Lviv State University of Internal Affairs, Lviv, Ukraine

\section{Oleksii Koval}

Bohdan Khmelnytsky National University of Cherkasy, Cherkasy, Ukraine

CMESTE

JEL Category: G21, G22, G23

\begin{abstract}
The need to form a system of economic security for the effective operation of financial institutions is determined. Peculiarities of ensuring economic security of different types of financial institutions are found out, characteristic features of functional systems of economic security of financial intermediaries are revealed. It is offered to understand the management of economic security of financial institutions as a direction of management activities aimed at achieving a high level of protection of the institution's resources from the negative impact of internal and external threats by implementing a wide range of management decisions to use available opportunities and resources while providing financial services. The basics of the mechanism of economic security management of financial institutions are formed. It is assumed that the organization of the economic security system of a financial institution is carried out in several stages, such as the formation of the economic security system, ensuring the economic security system, identification, assessment, ranking of threats, and development of countermeasures; assessing the level of readiness of institutions to implement a mechanism for managing economic security; assessment of the level of economic security, development of management decisions. It is determined that the purpose of economic security management is to achieve the maximum possible level of realization of the institution's interests and meet the interests and needs of clients with optimal resource costs to minimize the impact of threats that accompany the activities of institutions.
\end{abstract}

Keywords: economics, management, security, financial institutions, financial markets

Address of the corresponding author: Nataliia Zachosova 䒠”natazachosova@gmail.com

\section{INTRODUCTION}

An important problem of national security and defense of the state is to ensure a highly functional 
state of the critical infrastructure of the country, which is based on efficient and continuous operation of economic entities. The list of critical infrastructure of the state includes enterprises and institutions of such industries as energy, chemical industry, transport, banks and finance, information technology and telecommunications, food, health care, utilities, which are strategically important for the functioning of the economy and security of the state, society, and population. Thus, financial institutions, especially those that have the status of systemic and strategically important for the functioning of the internal financial market, belong to the objects of critical infrastructure of the state.

We have already paid attention to the study of fundamental issues of ensuring the economic security of financial institutions in previous studies (Zachosova, N. \& Babina, N. \& Zanora, V. (2018), Zachosova, N. (2019)). The issue of ensuring the proper functional condition of critical infrastructure facilities has also become known within the scientific community. (Alcaraz, C. \& Zeadally, S. (2015), Mosadeghi, R. \& Richards, R. \& Tomlinson, R. (2017), Giannopoulos, G. \& Filippini, R. \& Schimmer, M. (2012), Rehak, D. \& Senovsky, P. \& Slivkova, S. (2018), Pursiainen, C. (2018)). Given the differences in the tasks and mechanisms of different types of financial institutions, we conclude that there is currently no universal methodological approach to the formation of their economic security system as an object of management. Each system of economic security is a unique project, effective only for the type of financial institution for which it is designed and implemented. For the economic security system to be rational, it must be built based on a careful and professional study of all external and internal threats that affect the business processes of the financial institution. The functioning of the system of economic security of financial institutions should help ensure the state of their assets, which will allow them to conduct financial and investment activities without hindrance at the current time and guarantee such an opportunity in the future; provide resistance to the negative impact on the performance of institutions of external and internal threats, minimize the risks of adverse events for institutions, and in case of their occurrence, will compensate for the losses caused by them. The existence and functioning of an economic security system is a prerequisite for financial institutions to achieve a competitive advantage in the fight for consumers of financial services. Conceptual approaches to the formation of the economic security system as an independent object of management in the management system, which would be able to provide a full range of measures to protect the resources of financial institutions, regardless of the specifics of each type, but at the same time, was built taking into account functioning of business entities engaged in professional activities in the field of financial services.

For the formation of the system of economic security is important a specific scientific approach, the implementation of which in practice will achieve the stated goal.

In the process of forming the system of economic security of financial institutions as an object of management, it is important to take into account several rules tested at the applied level. Security experts sometimes call them "golden security rules":

- There are three concepts: safety, speed, and economy. When forming a system of economic security, you can choose only two indicators from these three. Choosing the optimal combination is the prerogative of managers who make management decisions.

- In the management of economic security, there are all economic laws and concepts, such as efficiency, although it is somewhat more difficult to calculate than financial efficiency because here the effect is not profiting savings, sometimes it is "virtual".

- Security and complexity of business processes - the phenomena are inversely proportional. The more complex the process, the more security issues there are, and the less reliable it is.

- Security is an investment, not an expense. It is expensive and a reasonable cost, but it does not mean that you need to invest in it indefinitely. There comes a time when a further increase in costs does not increase the level of economic security. Determining this point correctly means working cost-effectively. This can be called a kind of break-even point in the system of economic security.

- Any system of economic security slows down the development of the institution. The only 
way out is to follow the changes and predict the unknown.

Based on the above scientific paradigms and postulates, we will form a conceptual framework for managing the economic security of financial institutions.

\section{FORMATION OF THE ECONOMIC SECURITY SYSTEM OF FINANCIAL INSTITUTIONS}

The rapid increase in the number and intensity of threats affecting the activities of financial institutions in Ukraine has made their owners and managers realize the importance of building effective economic security systems. Industry 4.0 creates additional risks for the activities of financial institutions, which forces professionals in the management of financial and economic security to be more prudent in the formation of systems for its provision and use a systematic and comprehensive approach in the process of its management. Limited financial resources, which characterizes the current state of professional participants in the domestic financial market, does not allow them to incur unnecessary costs in the process of ensuring their economic security. Therefore, it is very important to establish effective management of the economic security system, because, in its absence, even professionally organized protection of resources will be ineffective and will not benefit the activities of the financial institution. The existing conceptual principles of forming the system of economic security of different types of financial institutions as an object of management, namely system (complex), hierarchical, functional, organizational - were formed on the practical basis of banks and insurance companies.

The formation of the system of economic security of financial institutions should be based on a mixed approach, which combines the features and characteristics of all four mentioned scientific approaches. Therefore, it is proposed to form a system of economic security of financial institutions, highlighting in its structure such elements as goals, objectives, functions, principles, functional components, mechanism, objects, entities, policies (which will include strategy, measures, evaluation indicators).
The expediency of introducing a system-process approach in the mechanism of managing the system of economic security of financial institutions is based on the following postulates.

First, at the stage of formation of the system of economic security of a financial institution as an object of management, it is necessary to realize that it can be neither identical to the system of production or trade enterprises, nor a template for different types of financial institutions. For banks, the list of its tasks must be broader than, for example, for the system of economic security of a credit union or pawnshop. Insurance companies, leasing companies, private pension funds, mutual investment institutions, and other types of financial intermediaries have their purpose and mechanisms for achieving it, which are different from each other, and therefore the organization of economic security management for each of them and even for different institutions within one type must be unique, because the level of its organization depends on the state of development and structure of financial potential, the efficiency of its use and direction of the institution, quality of personnel, labor discipline, competitive environment, risk of work, etc. Fulfillment of a wide range of different tasks to be solved within the functioning of economic security systems of financial institutions does not seem possible without the involvement of management staff, which suggests the need to build a mechanism for managing the economic security system of financial intermediaries.

Secondly, the system of economic security of a financial institution at the stage of its provision should be independent, individual, separated from similar systems of branches or subsidiaries. This circumstance should be emphasized, for example, when managing the economic security system of a bank that has an extensive network of branches or has related insurance or leasing companies (relatively independent, separate legal entities, but with a significant share of financial resources of the bank in its capital). But despite the necessary independence, the isolation of their economic security system is quite conditional, because the economic security system of any financial institution is an integral part of a higher-level security system - city, region, state, etc. A large number of tasks to ensure the economic security of financial institutions cannot be solved by them 
alone, without decisions taken at a higher systemic level, and primarily at the state level. As an example, we can cite the instructions of state regulators of financial market participants, such as NBU. It is at this level that the most important political, macroeconomic, legal, and other decisions are made, which form the environment of banking security and security of the nonbanking financial sector. The organization and functioning of the economic security system of a particular financial institution also depend on the activity of economic security services of competitive financial intermediaries, and above all, their intelligence units. It is created and operates based on legislative acts, depends on the possibility of acquiring means of protection, the level of training and qualification of personnel, and taking into account many external and internal factors. The need to respond to orders, their implementation, making independent decisions on the vectors of economic security of a financial institution as a separate economic unit on the one hand, and an element of the national economy on the other, proves the feasibility of managing the economic security of financial institutions.

Third, the system of economic security of modern financial institutions must be comprehensive. It is designed to ensure financial and investment, intellectual and personnel, information and analytical, technical and technological, physical (force), legal and external (territorial, market and legislative and political) security, etc. Consequently, it must contain the relevant elements, bodies, tools, resources, the search, and rational use of which involves the implementation of certain management work. There is a need to combine management actions aimed at ensuring the economic security of a financial institution, but the implementation of which is provided in different areas of its operation, using a system-process approach, into a single management mechanism capable of managing the economic security of financial institutions.

To implement the process of professional management of the economic security system in financial institutions, the internal subjects of such management must be identified. The best solution to this problem may be the creation of security services (or economic security) of financial institutions. The purpose of their security activities should be to prevent the leakage of commercial and confidential information, identify and prevent possible encroachments on the legal rights and interests of the financial institution, assess the effectiveness of resource management and economic security, assist managers in making management decisions, and more.

The responsibilities of the security or economic security service of the financial institution include the following tasks:

- protection of life and health of management staff and employees of the financial institution.

- protection of property, commercial and secret information, values of the financial institution, and other its resources.

- advising and recommending on issues of lawful protection against unlawful encroachments and conducting internal investigations.

- assessment of the level of economic security and advising the management of institutions in making management decisions based on the assessment.

To solve a wide range of functional tasks, the economic security service of a financial institution should work in close contact with marketing departments (if any), especially the study of competitors and competition conditions, ensuring the economic security of the financial institution in interaction with partners and customers, other external stakeholders.

\section{FINANCIAL INSTITUTIONS ECONOMIC SECURITY SYSTEM MANAGEMENT}

Defining the conceptual foundations of economic security management for different types of financial institutions allowed us to identify two possible models of economic security of financial institutions - comprehensive and fragmentary, to identify three options for economic security - selfsufficiency, transfer of security functions, mixed mechanism combining elements of previous two, to propose three approaches to ensuring the system of economic security - according to the first - security is a priority in the process of activity, according to the second - it is necessary to form a budget for security and accordingly the third security is at the expense of residual resources. Three approaches to the management of the economic security system used in practice are 
identified - profit-oriented, threat-oriented, customer-oriented, as well as the fourth approach, which is promising for application - reputationalimage; proposed the use of two models of security-oriented mechanism for managing the economic security system - basic and specificoriented (is a basic mechanism with the addition of a block of specific elements) and identified the need for three methods of assessing the level of economic security in the management of its security system, assessing the reliability of consumers of financial services, assessing the level of economic security from the standpoint of management.

Tasks of ensuring economic security, which must be performed at the level of economic entities, financial institutions:

- development of internal documentation for the organization and management of the system of economic (including financial and investment) security (Regulations on the economic security service, job descriptions of economic security management specialists, the Concept of economic security of a financial institution, economic security policy, etc.).

- introduction of periodic diagnostics of the state of economic security of the institution and its financial component.

- strict compliance with economic and financial standards established at the legislative level or the level of regulators.

- expanding the range of financial products and services.

- diversification of pricing policy of financial products and services.

- mandatory inspection of the state of economic and financial security of potential customers.

- creation of a single information base with free access for all types of financial institutions with information on persons who, as employees of financial institutions, committed fraudulent acts against them, misused insider information, dishonestly performed their duties, as well as data on financial client's institutions that have not fulfilled their financial obligations or have also been exposed to fraud against financial institutions and their resources. introduction of loyalty programs with special conditions for providing financial services for regular customers.

- diversification of activities in the direction of reducing the number of risky financial transactions.

- increase the level of information transparency by expanding the access of actual and potential clients to financial statements and other documents that specify certain aspects of financial institutions, and information from which can positively influence the decisions of individuals and legal entities to use financial products and services of a particular financial establish.

Thus, the essence of managing the economic security of financial institutions is that this process should be understood as a direction of management activities aimed at achieving a high level of protection of the institution's resources from the negative effects of internal and external threats by implementing a wide range of management decisions, resources to guarantee the economic interests of the financial institution and its customers in the provision of financial services. The object of management is the level of economic security, which ensures the functioning of the economic security system. The subjects of economic security management of financial institutions are divided into internal - which include the security service (economic security), employees, management staff, owners and managers of the institution, and external - the state represented by supervisory authorities, financial ombudsman, competitors, intermediaries, customers, counterparties and other categories of stakeholders.

The purpose of economic security management to achieve the maximum possible level of realization of the interests of the institution and meet the interests and needs of customers with optimal resource costs to minimize the impact of threats that accompany the activities of institutions. Functions of economic security management in general are reduced to the formation of a system of economic security, assessment of the level of economic security, management decisions. Forms of implementation of the management process are the creation of a unit for economic security, development of internal documentation, in particular the concept of 
economic security management, monitoring compliance with the rules and regulations adopted by the institution.

An important element of management is the evaluation of its effectiveness, which is analyzed based on the level of economic security that the institution has managed to achieve. Methods for assessing the level of economic security include: assessing the level of readiness of financial institutions to implement a mechanism for managing the economic security system, assessing the level of economic security from the standpoint of external stakeholders, assessing the reliability of consumers of financial services, internal assessment of economic security from the standpoint of management.

Management methods that should be used in the process of economic security management are: institutional and legal, administrative (organizational, directive, command), economic, organizational and technological, information, socio-psychological, legal, ideological, technological. Effective levers of management are administrative (state influence), organizational, economic, informational, socio-psychological.

Vectors of management force that can be recommended for use in the process of economic security management include organization and quality control of information and analytical support of the economic security system, selection, and control of personnel involved in the economic security system, system financing, risk management (in including reputation threat management), control of compliance with the law, optimization of resources used to ensure economic security, internal control, legal audit.

The organization of the economic security system of a financial institution is carried out in several stages, such as the formation of the economic security system, ensuring the economic security system, identification, assessment, ranking of threats and development of measures to counter them; assessing the level of readiness of institutions to implement a mechanism for managing economic security; assessment of the level of economic security, development of management decisions.

The implementation of the mechanism for managing the economic security system of a financial institution within the system-process approach should be based on compliance with certain principles. In particular, the management of economic security should be comprehensive, ie have signs of systematization in addressing issues of economic security with the mandatory involvement of representatives of management and all types of resources of the financial institution; be a continuous process, ie there should be a permanent evaluation of the functional components of the economic security system, a constant collection of data on the financial and economic condition of competitors and partners of the institution, its customers, and their analysis to prevent both internal and external threats to the financial institution; the principle of efficiency - ie rapid response to the manifestations of internal and external threats, timely notification of management of available data for informed management decisions; the principle of centralization - a single approach to the conscientious performance of ordinary employees while leaving the coordination role and methodological guidance of the unit or service of economic security of the financial institution and the principle of transparency - ie the maximum possible openness of management of the financial security of the financial institution).

Economic security system management of financial institutions should have a strategic and tactical level (and ideally - even operational). At the strategic level, an economic security management strategy or a strategy for the functioning of the economic security system should be developed, which would be organically integrated into the overall development strategy of the financial institution and guarantee its prospects for the future.

At the tactical level, it is recommended to develop specific management programs for financial and investment, intellectual and personnel, information and analytical, legal and other components of the economic security system, indicating the desired management results and the number of resources that can be spent. The implementation of these programs takes place at the operational level.

\section{CONCLUSIONS}

Thus, the study of the conceptual foundations of the formation of the system of economic security 
of financial institutions as an object of management has revealed the fact of a polystructural system of economic security, which involves the separation of several lower-level components. When forming the system of economic security of financial institutions, it is advisable to use a functional approach. But since the study revealed the existence of a large number of elements important for the effective functioning of the economic security system, and identified several levels at which the stages of building an economic security system, the need for both systemic (integrated) and hierarchical approaches cannot be denied to build a system of economic security of financial institutions.

The state of the economic security system of financial market participants, to the professional category of which financial institutions belong, is influenced by regulators of financial services markets and the securities and stock market, as well as the National Bank of Ukraine. Their instructions, orders, regulatory requirements lay the foundations of economic security, which must meet the activities of financial institutions. Therefore, the organizational approach to building a system of their economic security of financial institutions is also relevant. Thus, the formation of the system of economic security of financial institutions as an object of management should be a mixed approach, which combines the features and characteristics of all considered scientific approaches.

The management of the economic security system of financial institutions, taking into account all the above recommendations, is an important task facing the owners and management of financial market participants, given the many threats that accompany their activities in today's economic environment, and given the important role of financial institutions in ensuring the sustainability of the economic system of the state and in the process of ensuring the economic security of Ukraine, this task is currently gaining national importance. Focusing on the management of the economic security system of financial institutions for specific purposes will ensure a high level of readiness of financial institutions to implement a mechanism for managing the system of their economic security within security-oriented management and ensure the effectiveness of its operation.

Scientific works of many scientists do not answer the questions about what the strategic directions of economic security of financial institutions should be, in particular, in a political and economic crisis and the deployment of hostilities, hybrid war, and European integration, because such a combination of threats to the proper functioning of professional financial market participants in Ukraine has not existed since its independence. Therefore, it is necessary to form a list of strategic priorities in the management of the economic security of financial institutions, taking into account the specific circumstances in which they carry out their professional activities. This area of scientific research is planned to be chosen by the authors as a prospect for further research.

\section{WORKS CITED}

Alcaraz, C. \& Zeadally, S. (2015). Critical Infrastructure Protection: Requirements and Challenges for the 21st Century. International Journal of Critical Infrastructure Protection. 8. 53-66.

Giannopoulos, G. \& Filippini, R. \& Schimmer, M. (2012). Risk Assessment Methodologies for Critical Infrastructure Protection. Part I: A state of the Art. Luxembourg: Publications Office of the European Union, 53.

Mosadeghi, R. \& Richards, R. \& Tomlinson, R. (2017). Critical Infrastructure Protection and Uncertainty Analysis.

Pursiainen, C. (2018). Critical Infrastructure Resilience: A Nordic Model in the Making? Int. J. Disaster Risk Reduct, 27. 653390. 632-641.

Rehak, D. \& Senovsky, P. \& Slivkova, S. (2018). Resilience of Critical Infrastructure Elements and Its Main Factors. Systems. 6. 21. 
Zachosova, N. \& Babina, N. \& Zanora, V. (2018). Research and methodological framework for managing the economic security of financial intermediaries in Ukraine. Banks and Bank Systems. 13. 4. 119-130.

Zachosova, N. (2019). Innovative approach in the estimatology of financial institutions economic security: possibilities of use in management and regulatory activity within the means of provision of the state financial security. Baltic Journal of Economic Studies. 5/2.45-56.

Received for publication: $\quad$ 03.09.2020

Revision received: $\quad 23.09 .2020$

Accepted for publication: $\quad 30.12 .2020$

\section{How to cite this article?}

Style - APA Sixth Edition:

Zachosova, N., Zyvko, Z., \& Koval, O. (2021, January 15). Economic security management of financial institutions as objects of the state critical infrastructure. (Z. Cekerevac, Ed.) MEST Journal, 9(1), 216-223. doi:10.12709/mest.09.09.01.25

Style - Chicago Sixteenth Edition:

Zachosova, Nataliia, Zinaida Zyvko, and Oleksii Koval. 2021. "Economic security management of financial institutions as objects of the state critical infrastructure." Edited by Zoran Cekerevac. MEST Journal (MESTE) 9 (1): 216-223. doi:10.12709/mest.09.09.01.25.

Style - GOST Name Sort:

Zachosova Nataliia, Zyvko Zinaida and Koval Oleksii Economic security management of financial institutions as objects of the state critical infrastructure [Journal] // MEST Journal / ed. Cekerevac Zoran. - Belgrade - Toronto : MESTE, January 15, 2021. - 1 : Vol. 9. - pp. 216-223.

Style - Harvard Anglia:

Zachosova, N., Zyvko, Z. \& Koval, O., 2021. Economic security management of financial institutions as objects of the state critical infrastructure. MEST Journal, 15 January, 9(1), pp. 216-223.

Style - ISO 690 Numerical Reference:

Economic security management of financial institutions as objects of the state critical infrastructure. Zachosova, Nataliia, Zyvko, Zinaida and Koval, Oleksii. [ed.] Zoran Cekerevac. 1, Belgrade Toronto : MESTE, January 15, 2021, MEST Journal, Vol. 9, pp. 216-223. 